УДК 621.396.963:621.391.26

\title{
МНОГОСТУПЕНЧАТАЯ АДАПТИВНАЯ КОМПЕНСАЦИЯ АКТИВНЫХ ШУМОВЫХ ПОМЕХ С БЛОЧНОЙ ОРТОГОНАЛИЗАЦИЕЙ СИГНАЛОВ КОМПЕНСАЦИОННЫХ КАНАЛОВ
}

\author{
С. Я. ЖУК ${ }^{1}$, К. М. СЕМИБАЛАМУТ ${ }^{2}$, С. Н. ЛИТВИНЦЕВ ${ }^{1}$ \\ ${ }^{1}$ Национальный технический университет Украинь \\ «Киевский политехнический институт им. Игоря Сикорского», \\ Украина, Киев, 03056, пр-т Победы 37 \\ ${ }^{2}$ Военно-дипломатическая академия имени Евгения Березняка, \\ Украина, Киев, 04050, ул. Мельникова 81
}

\begin{abstract}
Аннотация. С использованием блочной ортогонализации Грама-Шмидта и LS-алгоритма по критерию наименьших квадратов синтезированы многоступенчатые цифровые автокомпенсаторы активных шумовых помех, которые обеспечивают параллельно-последовательную обработку сигналов. Применение RLS-алгоритма позволило получить рекуррентную процедуру вычисления весовых коэффициентов модулей автокомпенсатора, представленных в виде многовходовых весовых сумматоров. Анализ многоступенчатых цифровых автокомпенсаторов на основе RLS-алгоритма с одновременной адаптацией весовых сумматоров всех ступеней выполнен с помощью статистического моделирования на ЭВМ. В результате распараллеливания вычислительного процесса синтезированные многоступенчатые автокомпенсаторы позволили увеличить скорость обработки (частоту дискретизации сигнала) на порядок и более по сравнению с автокомпенсаторами, построенными по одноступенчатой схеме.
\end{abstract}

Ключевые слова: автокомпенсаторы помех; цифровые антенные решетки; метод наименьших квадратов; LS- и RLS-алгоритм; ортогонализация Грама-Шмидта

\section{ВВЕДЕНИЕ}

Для пространственной компенсации активных шумовых помех в радиолокационных системах различного назначения широкое применение находят автокомпенсаторы помех на основе цифровых антенных решеток [1]. Традиционно алгоритмы пространственной фильтрации характеризуются высокой вычислительной сложностью, что затрудняет их реализацию в реальном масштабе времени [2, 3].

Одним из основных направлений повышения быстродействия вычислительных средств в многофункциональных радиолокационных системах является распараллеливание алгоритмов с последующей одновременной обра- боткой по всем параллельным каналам [3]. В этом случае система обработки состоит из модулей (спецпроцессоров) и реализуется на основе многопроцессорных вычислительных систем. Поэтому разработка методов распараллеливания алгоритмов пространственной фильтрации помех является актуальной задачей радиолокации.

Перспективным является подход, основанный на ортогональных преобразованиях сигналов [4, 5]. Он позволяет получить алгоритмы, которые обеспечивают параллельно-последовательную обработку сигналов. Идеи и способы построения адаптивных сис- 


\section{БИБЛИОГРАФИЧЕСКИЙ СПИСОК}

1. Радиоэлектронные системы: Основы построения и теория. Справочник. Издание второе, переработанное и дополненное. Под редакцией Я.Д.Ширмана. М. : Радиотехника, 2007. 828 с.

2. Быстров, Р.П.; Новиков, А.В.; Румянцев, В.Л.Повышение быстродействия пространственной фильтрации помех в РЛС с АФАР. Журнал радиоэлектроники, № 11, 2014. http://jre.cplire.ru/alt/nov14/11/ text.html.

3. Кузьмин, С.3. Цифровая радиолокаиия. К. : КВиЦ, 2000. 428 с.

4. Ратынский, М.В. Адаптация и сверхразрешение в антенных решетках. М. : Радио и связь, 2003. $200 \mathrm{c}$.

5. Monzingo, Robert A.; Haupt, Randy L.; Miller, Thomas W. Introduction to Adaptive Arrays, 2nd ed. Scitech Pub., Inc., 2011. 510 p.

6. Леховицкий, Д.И.; Рачков, Д.С.; Семеняка, А. В.; Рябуха, В.П.; Атаманский, Д. В. Адаптивные решетчатые фильтры. Часть I. Теория решетчатых структур. Прикладная радиоэлектроника, Т. 10, № 4. С. 381-404, 2011.

7. Гираудон, С. Пат. № 3876847 США, МКИ $325 / 367$ от 8.04 .1975 .

8. Лексаченко, В.А.; Шаталов, А. А. Синтез многомерного «выбеливающего» фильтра по методу Грама-Шмидта. Радиотехника и электроника, Т. 21, № 1. C. $112-119,1976$.

9. Полов, К. П. Адаптивный компенсатор помех. Радиотехника, Т. 34, № 1. С. 19-24, 1979.

10. Бондаренко, Б. Ф.; Прокофьев, В.П.Применение методов функционального анализа для решения задачи синтеза системы пространственной обработки. Известия вузов. Радиоэлектроника, Т. 25, № 7. С. 12-16, 1982.

11. Коуэн, К.Ф.Н.; Грант, П.М. (ред.) Адаптивные фильтры. Пер. с англ. М. : Мир, 1988. 392 с.

12. Джиган, В.И. Адаптивная фильтраџия сигналов: теория и алгоритмы. М. : Техносфера, 2013. $528 \mathrm{c}$.

13. Себер, Дж. Линейный регрессионный анализ. Пер. с англ. В.П.Носко под ред. М.Б. Малютова. М. : Мир, 1980. 456 с.

14. Хокни, Р.; Джесхоуп, К. Параллельные ЭВМ. М. : Радио и связь, 1986.

15. Стренг, Г. Линейная алгебра и ее применения. М. : Мир, 1980. 459 с.

16. Жук, С. Я.; Семибаламут, К. М.Двухступенчатая адаптивная компенсация активных шумовых помех с ортогонализацией сигналов части компенсаци- 
онных каналов. Вестник НТУУ «КПИ». Серия Радиотехника. Радиоаппаратостроение, № 64. С. 61-74, 2016. URL: http://radap.kpi.ua/ru/radiotechnique/article/ view/1172.

17. Тихонов, В.И.; Харисов, В.Н. Статистический анализ и синтез радиотехнических устройств и систем. М. : Радио и связь, 1991. 608 с.

18. Леховицкий, Д.И.; Рябуха, В.П.; Жуга, Г.А.; Лаврентьев, В.Н.Экспериментальные исследования систем СДЦ на основе адаптивных решетчатых фильтров в импульсных РЛС с попачечной вобуляцией периодов зондирования. Прикладная радиоэлектроника, Т. 7, № 1. С. 90-101, 2008.

19. Ефремов, В.С. Адаптивные системы селекции движущихся целей в радиолокаторах управления воздушным движением. Вестник МГТУ им. Н. Э. Баумана. Сер. Приборостроение, № 2. С. 3-16, 2007. URL: http://vestnikprib.ru/catalog/radoiel/hidden/274.html.

20. Леховицкий, Д. И.; Атаманский, Д. В.; Рачков, Д. С.; Семеняка, А. В. Оценка энергетических спек- тров отражений в импульсных доплеровских метеорадиолокаторах. Ч. 1. Разновидности алгоритмов спектрального оценивания. Известия вузов. Радиоэлектроника, Т. 58, № 12, С. 3-30, 2015. DOI: $10.20535 / \mathrm{S} 0021347015120018$.

21. Леховицкий, Д. И.; Атаманский, Д. В.; Рачков, Д. С.; Семеняка, А. В. Оценка энергетических спектров отражений в импульсных доплеровских метеорадиолокаторах. Ч. 2. Предельные возможности. Известия вузов. Радиоэлектроника, Т. 59, № 9, С. 3-20, 2016. DOI: 10.20535/S0021347016090016.

22. Леховицкий, Д. И.; Атаманский, Д. В.; Рачков, Д. С.; Семеняка, А. В. Оценка энергетических спектров отражений в импульсных доплеровских метеорадиолокаторах. Ч. 3. Статистический анализ методов воспроизведения непрерывных спектров отражений от метеообразований. Известия вузов. Радиоэлектроника, Т. 60, № 2, С. 59-96, 2017. DOI: $10.20535 / \mathrm{S} 0021347017020017$. 